\title{
PERANAN KURATOR TERHADAP KEPAILITAN PERSEROAN TERBATAS
}

\author{
Oleh: \\ Alusianto Hamonangan \\ David Tambunan \\ Universitas Darma Agung, Medan \\ E-mail: \\ alusiantohamonangan@gmail.com \\ davidsmyulianto14@gmail.com
}

\begin{abstract}
A limited company that is declared bankrupt does not immediately stop and dissolve but still exists as a legal entity. Under certain circumstances it still exists to run its business, as usual, a limited liability company does not go bankrupt and can still carry out its business activities. This is because the company is declared bankrupt and has an economic value that is much higher than the value of the company's assets. Because bankruptcy is actually intended for companies that have negative assets. However, the decision to continue the bankruptcy company resulted in the power of the board of directors in a limited company. However, with the bankruptcy declaration, the debtor for the sake of law loses the right to control and manage his assets which are included in the bankruptcy estate as of the day of the declaration of bankruptcy. This study uses a juridical normative method, in which all sources are taken from literature, laws and other media. In the event of a limited liability company bankruptcy, the curator has the obligation to be able to manage and settle all bankruptcy assets and keep all related documents. As a result of the law that occurs from the bankruptcy of a limited liability company, it is hoped that the management of the company will carry out their duties and authority to the maximum in order to avoid bankruptcy which results in large losses to the company, especially losses incurred to debtors.
\end{abstract}

\section{Keywords: Bankruptcy, Curator, Limited Liability Company}

\begin{abstract}
ABSTRAK
Perseroan terbatas yang dinyatakan pailit tidak serta merta berhenti dan bubar melainkan masih eksis sebagai badan hukum. Dalam keadaan tertentu masih eksis menjalankan usahanya seperti lazimnya perseroan terbatas tidak terjadi kepailitan dan tetap dapat melakukan kegiatan usahanya. Hal ini diakibatkan perseroan dinyatakan pailit mempunyai nilai ekonomis (economic value) yang jauh lebih tinggi dibanding nilai aset perusahaan tesebut. Oleh karena kepailitan sebenarnya diperuntukkan terhadap perusahaan yang mempunyai aset negatif. Namun demikian, keputusan untuk melanjutkan perseroan pailit mengakibatkan kekuasaan direksi dalam suatu perseroan terbatas.. Namun dengan adanya pernyataan pailit, debitor demi hukum kehilangan hak untuk menguasai dan mengurus harta kekayaannya yang dimasukkan ke dalam harta pailit terhitung
\end{abstract}


sejak hari putusan pernyataan pailit tersebut. Penelitian ini menggunakan metode normatif yuridis, yaitu segala sumber di ambil dari kepustakaan, undang-undang dan media lainnya. Dalam hal terjadinya kepailitan perseroan terbatas, kurator memilki kewajiban untuk dapat mengurus dan membereskan segala harta pailit dan menyimpan semua dokumen yang berkaitan. Akibat hukum yang terjadi dari kepailitan perseroan terbatas maka diharapkan kepada pengurus perseroan melakukan tugas dan wewenangnya semaksimalnya agar terhindar dari kepailitan yang berakibat kerugian besar perusahaan, terutama kerugian yang terjadi kepada debitur.

\section{Kata Kunci : Kepailitan, Kurator, Perseroan Terbatas}

\section{PENDAHULUAN}

Perekonomian memang sekarang ini mengatami keterpurukan karena sedang dilanda krisis virus Corona atau Covid 19, sehingga mempengaruhi segala aspek kehidupan masyarakat Indonesia. Hal ini dapat dilihat dari tingginya kebutuhan hidup yang harus dipenuhi, sementara pendapatan sebagian besar masyarakat masih relatif rendah, akibatnya banyak anggota masyarakat kesulitan dalam mengembangkan bidang usaha termasuk untuk memenuhi kebutuhan hidup sehari-hari maupun membuka atau memperluas bidang usahanya. Demikian juga pada perusahaan-perusahaan tersebut, sehingga pada akhirnya harus mengalami kepailitan, dikarenakan tidak sanggup memenuhi kewajibannya dalam melaksanakan aktifitas atau kegiatan perusahaan, salah satunya perusahaan yang mengalami kepailitan tersebut ialah perusahaan Perseroan Terbatas

\footnotetext{
a Secara umum kepailitan mengakibatkan seluruh kekayaan debitur segala sesuatu yang diperoleh selama kepailitan berada dalam sitaan umum sejak saat putusan pernyataan pailit diucapkan, penting untuk dipahami bagi suatu perseroan terbatas selaku debitur dalam kepailitan, adanya pernyataan pailit oleh suatu putusan pengadilan, maka perseroan yang bersangkutan demi kehilangan haknya untuk menguasai dan mengurus harta kekayaannya yang masuk dalam harta pailit.
}

Dalam

Undang-Undang

Kepailitan jelas disebutkan bahwa yang dimaksud dengan kurator adalah Balai Harta Peninggalan atau orang perseorangan yang diangkat oleh pengadilan untuk mengurus dan membereskan harta debitur pailit di bawah pengawasan Hakim Pengawas sesuai dengan undang-undang ini (pasal 1 angka 5). Melihat pentingnya kurator dalam kepailitan perseroan terbatas, maka Undang-Undang Kepailitan juga mengatur terkait dengan kewenangan, tugas dan kewajiban kurator. Terlepas dari kewajiban kurator mempertahankan kerahasiaan hal-hal yang berkaitan dengan penugasannya, kurator dalam bekerja tentu bukan tanpa tanggungjawab, bahkan beban tanggungjawab seorang kurator itu sangat berat.

Kurator bukan saja
bertanggungjawab pada satu pihak namun juga dua belah pihak dan apabila ada kesalahan karena perbuatan yang dilakukan dengan sengaja tetapi juga karena kelalaian. Setiap perbuatan kurator yang merugikan harta pailit ataupun dalam arti merugikan kepentingan kreditor, baik secara sengaja maupun tidak sengaja oleh kurator, maka kurator harus dapat mempertanggungjawabkan

perbuatannya. Hal ini tegas dinyatakan dalam pasal 72 Undang-undang Kepailitan.

\section{TINJAUAN PUSTAKA}




\section{Pengertian Kurator}

diberi Kurator adalah pihak yang pengurusan dan/atau harta pailit, kurator merupakan lembaga yang diadakan oleh undang-undang untuk melakukan pemberesan terhadap harta pilit, kurator bertugas menurut undang-undang, mengurus, dan membereskan harta pailit, dalam setiap putusan pailit oleh pengadilan, maka didalamnya terdapat pengangkatan kurator yang ditunjuk untuk melakukan pengurusan dan pengalihan harta pailit dibawah pengawasan hakim pengawas. "Segera setelah debitor dinyatakan pailit oleh pengadilan, maka si pailit demi hukum tidak berwenang melakukan pengurusan dan atau pengalihan terhadap harta kekayaanya yang sudah menjadi harta pailit. Kuratorlah yang melakukan segala tindakan hukum baik pengurusan maupun pengalihan terhadap harta pailit, dibawah pengawasan hakim pengawas. Dari proposisi ini, maka tampak bahwa kurator sangat menentukan terselesaikannya pemberesan harta pailit. Karena itu, undang-undang sangat ketat dan rinci sekali memberikan kewenangan apa yang dimiliki oleh kurator serta tugas apa saja yang harus dilakukan oleh kurator.

Kurator tidak boleh ada conflict of interest (benturan kepentingan) di dalamnya, kurator harus lah independen. Hal itu karena demikian besar kewenangn dari kurator terhadap harta pailit. Kurator harus berpihak kepada hukum. Di dalam praktiknya penetapan nama kurator yang ditunjuk itu diajukan oleh kreditor yang mengajukan permohonan pailit terhadap debitor. Namun demikian kendatipun diusulkan oleh kreditor tersebut kurator harus tetap independen karena ia akan bertanggung jawab terhadap apa yang dilakukannya, tanggungjawab dari kurator inilah merupakan landasan hukum untuk mengawasi tindakan hukum dari kurator.

Dalam Pasal 72 UndangUndang Kepailitan secara tegas dikatan bahwa kurator bertanggungjawab terhadap kesalahan atau kelalaiannya dalam melaksanakan tugas penerusan dan atau pemberesan yang menyebabkan kerugian terhadap harta pailit. Karena wewenang kurator yang sedemikian luasnya memerlukan rambu-rambu hukum yang pasti serta menghidarkan interpretasi yang meluas mengingat cakupan norma yag ada dalam Pasal 1365 KUHPerdata terlalu fleksibel. Disamping juga dalam praktiknya tidak sedikit kurator yang menyalahgunakan kekuasaaanya sebagai kurator."

\section{Peranan Kurator}

Peran yang dominasi dilakukan kurator adalah bertindak sebagai penyelesaian masalah kepailitan yang dialami oleh debitur dimana kurator tidak bertindak untuk kepentingan pemohon melainkan untuk kepentingan budel pailit. Hal ini berarti bahwa peran kurator tidak melulu lebih mendahulukan kepentingan kreditur, tapi harus fair juga terhadap debitur selaku yang mengalami kepailitan. Kedudukan kurator tentunya lebih tinggi dibanding debitur artinya kurator sepenuhnya memiliki hak untuk mengatur pengurusan dan pemberesan harta yang pailit apabila telah terjalin sebuah kerjasama yang artinya debitur sudah mempercayakan segala bentuk proses pada kurator.

Adapun beberapa hal yang dilakukan oleh kurator adalah sebagai berikut:

a. Dalam rangka pengurusan proses harta pailit kurator mengambil kebijakan dengan memberikan pengumuman kepailitan melalui surat harian yang telah dikonsultasikan dengan hakim pengawas dalam jangka waktu 5 hari. Pengumuman tidak diharuskan memperoleh persetujuan dari atau menyampaikan pemberitahuan terlebih dahulu kepada debitur karena kurator 
memiliki kedudukan dapat langsung mengambil untuk mengamankan benda-benda berharga milik debitur pailit seperti uang, saham, deposito, perhiasan-perhiasan atau lainnya milik debitur pailit. Walaupun benda-benda tersebut berada pada pihak lain misalkan kondisi rumah masih ada dalam proses bangun maka kedudukannya menjadi hak kurator untuk dilelang atau diproses dalam bentuk jual beli dibawah harga pasar. Dengan adanya "pengumuman" putusan pernyataan pailit tersebut, maka berlakulah ketentuan undangundang atas seluruh harta kekayaan debitor pailit, yang berlaku umum bagi semua kreditor konkuren dalam kepailitan, tanpa terkecuali untuk memperoleh pembayaran atas seluruh piutang-piutang konkuren mereka .

b. Sebelum melakukan lelang ataupun jual beli kurator memiliki peran dalam membuat pencatatan/pendaftaran harta kekayaan dari debitur yang mengalami pailit dan memisahmisahkan barang yang cepat rusak karena barangbarang yang kurang layak ataupun masih baik supaya dapat dijual secepatnya untuk menutupi biaya Kepailitan sementara. Penjualan tersebut merpakan salah satu langkah pemberesan sehingga secara pidana kurator tidak bersalah karena sudah ada perjanjian kerjasama selama barang yang dijual dalam koridor kepailitan.

\section{Prosedur Pengajuan Kepailitan}

a. Diajukan ke Pengadilan (Niaga) yang daerah hukumnya merupakan kedudukan hukum debitor.

b. Apabila debitor telah keluar negeri, ke pengadilan yang daerah hukumnya meliputi tempat kedudukan terakhir,

c. Dalam hal debitor tidak bertempat kedudukan dalam wilayah Republik Indonesia, tetapi menjalankan profesi dan usahanya dalam wilayah Indonesia, diajukan ke pengadilan yag daerah hukumnya meliputi tempat kedudukan hukum, kantor debitor menjalankan profesi/usaha.

d. Harus diajukan oleh seorang penasihat hukum yang memiliki izin praktik.

e. Setelah diputuskan dalam jangka waktu paling lambat 5 (lima) hari sejak putusan pernyataan pailit, curator mengumumkan dalam berita Negara Republik Indonesia, serta sekurang-kurangnya dalam 2 (dua) surat kabar harian yang ditetapkan oleh hakim pengawas.

\section{METODE PELAKSANAAN}

Untuk membahas permasalahan yang telah dirumuskan dan dibatasi sebagaimana tersebut diatas, maka dalam metode penyusunan dan penyelesaian peneliti dalam penelitian ini, akan dipergunakan metode dan teknik penelitian sebagaimana dibawah ini. Jenis penelitian yang digunakan dalam penelitian ini adalah yuridis normatif. Suatu analisa normatif pada hakekatnya menekankan pada metode deduktif sebagai pegangan utama dan metode induktif sebagai tata kerja penunjang. Analisa yuridis normatif terutama mempergunakan bahan-bahan kepustakaan sebagai sumber data penelitiannya.

Teknik pengumpulan data yang digunakan adalah studi pustaka dan studi dokumen, yaitu pengumpulan data yang dicari dari buku, undang-undang dan literature lain yang terkait. 
Melakukan studi kepustakaan yang bersumber dari bahan hukum primer, sekunder dan tertier. Bahan hukum primer adalah bahan-bahan yang isinya mengikat karena di keluarkan oleh Pemerintah, misalnya Undang-Undang, traktat dan lain-lain. Bahan hukum sekunder adalah bahan-bahan yang substansinya membahas bahan hukum primer, misalnya buku, artikel dan karya tulis ilmiah.

\section{HASIL DAN PEMBAHASAN \\ A. Tanggungjawab Perseroan Terbatas Atas}

Prinsip commercial exit from financial distress dari kepailitan memberikan makna bahwa kepailitan adalah solusi dari masalah penyelesaian utang debitur yang sedang mengalami kebangkrutan dan bukan sebaliknya bahwa kepailitan justru digunakan sebagai pranata hukum untuk membangkrutkan suatu usaha. Kemudahan untuk mempailitkan suatu debitur sebenarnya tidak bertentangan dengan prinsip ini sepanjang kemudahan untuk mempailitkan adalah dalam konteks penyelesaian utang karena adanya kesulitan financial dari usaha debitur.

Kebangkrutan perseroan terbatas adalah suatu keadaan dimana perusahan mengalami deteriorasi adaptasi perusahaan dengan lingkungannya yang sampai membawa akibat pada rendahnya kinerja untuk jangka waktu tertentu yang berkelanjutan yang pada akhirnya menjadikan perusahan tersebut kehilangan sumber daya dan dana yang dimiliki sebagai akibat dari gagalnya perusahaan melakukan pertukaran yang sehat antara pengeluaran dan masukan yang diperoleh.

Mengenai tanggung jawab direksi apabila perusahaan mengalami kepailitan dapat kita lihat aturannya dalam Pasal 104 UUPT, yang berbunyi sebagai berikut: a. Direksi tidak berwenang mengajukan permohonan pailit atas perseroan sendiri kepada pengadilan niaga sebelum memperoleh persetujuan RUPS, dengan tidak mengurangi ketentuan sebagaimana diatur dalam Undang-Undang tentang Kepailitan dan Penundaan Kewajiban Pembayaran Utang.

b. Dalam hal kepailitan sebagaimana dimaksud pada ayat (1) terjadi karena kesalahan atau kelalaian Direksi dan harta pailit tidak cukup untuk membayar seluruh kewajiban Perseroan dalam kepailitan tersebut, setiap anggota Direksi secara tanggung renteng bertanggung jawab atas seluruh kewajiban yang tidak terlunasi dari harta pailit tersebut.

c. Tanggung jawab sebagaimana dimaksud pada ayat (2) berlaku juga bagi anggota Direksi yang salah atau lalai yang pernah menjabat sebagai anggota Direksi dalam jangka waktu 5 (lima) tahun sebelum putusan pernyataan pailit diucapkan.

d. Anggota Direksi tidak bertanggungjawab atas kepailitan Perseroan sebagaimana dimaksud pada ayat (2) apabila dapat membuktikan:

1. kepailitan tersebut bukan karena kesalahan atau kelalaiannya

2. telah melakukan pengurusan dengan itikad baik, kehati-hatian, dan penuh tanggungjawab untuk kepentingan Perseroan dan sesuai dengan maksud dan tujuan Perseroan.

3. tidak mempunyai benturan kepentingan baik langsung maupun tidak langsung atas tindakan pengurusan yang dilakukan 
4. telah mengambil tindakan untuk mencegah terjadinya kepailitan.

Sedangkan jika dilihat dari substansinya, maka tanggungjawab direksi perseroan terbatas dibedakan setidak-tidaknya menajdi empat kategori, yakni :

1. Tanggungjawab berdasarkan prinsip fiduciary duties dan duty to skill and care, tugas yang terbit secara hukum dari suatu hubungan antara direksi dan perusahaan yang dipimpinnya, sehingga seorang direksi haruslah mempunyai kepedulian dan kemampuan, itikad baik. Loyalitas dan kejujuran terhadap perusahaannya denagn derajat yang tinggi. Tidak hanya ia bertanggungjawab ketidakjujuran yang disengaja, tetapi ia bertanggungjawab juga secara hukum terhadap tindakan missmanajemen,kelalaian aatu kegagalan atau tidak melakukan sesuatu yang penting bagi perusahaan.

2. Tanggungjawab berdasarkan doktrin manajemen ke dalam (indoor management rule), merupakan doktrin kontemporer yang mengajarkan bahwa jika pihak yang menjalankan tugas-tugas perusahaan dalam menjalankan tugas-tugasnya dengan isi anggaran dasar perseroan, maka pihak perusahaan terikat dengan pihak yang ketiga atas segala tindakan yang telah dilakukan oleh perusahaan tersebut, meskipun dalam menjalankan tugas itu, pihak perusahaan tidak memenuhi ketentuan internal perseroan dan meskipun pihak luar perusahaan yang telah diumumkan kepada publik.

Tanggungjawab direksi berdasarkan doktrin manajemen ke dalam ini diberi batasan-batasan, antara lain :

a. Pihak yang melakukan kegiatan perseroan memang berwenang melakukannya b. Para pihak telah tidak berpegang pada dokumendokumen yang dipalsukan

c. Pihak ketiga yang melakukan kegiatan dengan perseroan merupakan pihak ketiga yang beritikad baik

d. Pihak ketiga yang melakukan kegiatan dengan perseroan telah melakukan penyelidikan yang layak terhadap transaksi tersebut.

3. Tanggungjawab berdasarkan prinsip ultra vires (pelampauan kewenangan perseroan), suatu prinsip yang mengatur akibat hukum seandainya ada tindakan direksi untuk dan atas nama perseroan, tetapi tindakan direksi tersebut sebenarnya melebihi dari apa yang diatur dalam anggaran dasar perseroan. Doktrin ultra vires berdampak pada perikatan antara perseroan dan pihak ketiga, dimana transaksi yang dilakukan bersifat ultra vires.

4. Tanggungjawab berdasarkan prinsip piercing the coporate veil, suatu proses untuk membebani tanggungjawab ke pundak orang atau perusahaan lain atas tindakan hukum yang dilakukan oleh perusahaan pelaku, tanpa mempertimbangkan bahwa sebenarnya perbuatan tersebut dilakukan atas nama perseroan pelaku. Doktrin ini juga dianut dalam UUPT, dikatakan bahwa pemegang saham perseroan tidak bertanggungjawab secara pribadi atas perikatan yang dibuat atas nama perseroan dan tidak bertanggungjawab atas kerugian perseroan melebihi nilai saham yang telah diambilnya.

Pada prinsipnya tanggungjawab direksi perseroan terbatas yang perusahaannya mengalami kepailitan adalah sama dengan tanggungjawab direksi yang perusahannya tidak sedang mengalami kepailitan. Ada beberapa kondisi yang merupakan pengaturan lebih lanjut dari kelembagaan direksi 
berkaitan dengan kepailitannya perseroan terbatas ini. Pada prinsipnya direksi tidak bertanggungjawab secara pribadi terhadap perbuatan yang dilakukan untuk dan atasa nama perseroan berdasarkan wewenang yang dimiliki.

Hal ini karena perbuatan direksi dipandang sebagai perbuatan perseroan terbatas yang merupakan subjek hukum mandiri sehingga perseroanlah yang bertanggungjawab terhadap perbuatannya perseroan itu sendiri yang dalam hal ini direpresentasikan oleh direksi. Namun dalam beberapa hal direksi dapat pula dimintai pertanggungjawabannya secara pribadi dalam kepailitan perseroan terbatas ini.

Ketentuan normatif mengenai tanggungjawab direksi dalam hal terjadinya kepailitan perseroan terbatas adalah apa yang dikonstatir dalam pasal 104 ayat 2 UUPT 2007. Dalam hal kepailitan sebagaimana dimaksud pada ayat 1 terjadi karena kesalahan atau kelalaian direksi dan harta pailit tidak cukup untuk membayar seluruh kewajiban yang tidak terlunasi dari harta pailit tersebut. Perseroan sebagaimana dimaksud pada ayat 2 apabila dapat membuktikan :

a. Kepailitan tersebut bukan karena kesalahan atau kelalaiannya

b. Telah melakukan pengurusan dengan itikaq baik, kehatihatian dan pe4nuh tanggungjawab untuk kepentingan perseroan dan sesuai dengan maksud dan tujuan perseroan

c. Tidak mempunyai benturan kepentingan baik langsung maupun tidak langsung atas tindakan pengurusan yang dilakukan

d. Telah mengambil tindakan untuk mencegah terjadinya kepailitan.

\section{B. Akibat Hukum Kepailitan Perseroan Terbatas}

Akibat hukum yang ditimbulkan oleh kepailitan, sekalipun tidak sama sekali menghilangkan kecakapan untuk bertindak, mendekati akibat hukum terhadap sesorang yang ditempatkan dibawah pengampuan. Jika perseroan yang dinyatakan pailit, maka perseroan tidak biasa melakukan tindakan pengurusan dan pemilikan yang membawa akibat hukum yang merugikan harta kekayaan perseroan. Pernyataan pailit mengakibatkan harta kekayaan debitor sejak putusan itu dikeluarkan dimasukkan ke dalam harta pailit.

Menurut pasal 21 UUK, Seluruh harta kekayaan yang ada pada saat pernyataan pailit diputuskan, maupun terhadap semua kekayaan yang diperoleh debitor selama debitor berada dalam kepailitan. Dengan adanya pernyataan pailit, debitor demi hukum kehilangan hak untuk menguasai dan mengurus harta kekayaannya yang dimasukkan ke dalam harta pailit terhitung sejak hari putusan pernyataan pailit tersebut. Apabila setelah putusan pernyataan pailit debitor masih juga tetap melakukan perbuatan hukum yang menyangkut harta kekayaannya, maka perbuatan hukum itu tidak mengikat kecuali apabila perikatan-perikatan yang dibuat itu mendatangkan keuntungan bagi harta pailit.

Dengan dinyatakannya pailit, maka debitor tidak memiliki kewenangan melakukan tindakan pengurusan dan pemilikan terhadap harta kekayaannya (asetnya). Namun demikian, tidak menghilangkan sama sekali kewenangan debitor untuk melakukan pengurus selama mendatangkan keuntungan bagi harta pailit tersebut bahwa pernyataan pailit tidak dengan sendirinya mengakibatkan perseroan bubar. Oleh karenanya perseroan pailit tetap cakap dan berwenang melakukan perbuatan hukum. Perseroan tetap dapat melanjutkan kegiatan usahanya kecuali dibubarkan. Pertimbangan utama melanjutkan kegiatan usaha perseroan terbatas yang dinyatakan pailit adalah 
nilai ekonomis (economic value) perusahaan yang jauh lebih tinggi dibanding nilai aset perusahaan tesebut. Oleh karena kepailitan sebenarnya diperuntukkan terhadap perusahaan yang mempunyai aset negatif. Namun demikian, keputusan untuk melanjutkan perseroan pailit mengakibatkan kekuasaan direksi dalam suatu perseroan terbatas dan badan-badan hukum lainnya yang mengelola perusahaan debitor atau badan hukum tersebut "terpasung", sekalipun mereka tetap menjabat dalam jabatannya tersebut.

\section{Akibat Kepailitan Secara Umum}

Kepailitan mengakibatkan seluruh kekayaan debitur serta segala sesuatuyang diperoleh selama kepailitan berada dalam sitaan umum sejak saat putusan pernyataan pailit diucapkan, kecuali :

a. Benda, termasuk hewan yang benar-benar dibutuhkan debitur sehubungan dengan pekerjaannya, perlengkapannya, alat-alat medis yang dipergunakan untuk kesehatan, tempat tidur dan perlengkapannya yang dipergunakan oleh debitur dan keluarganya yang terdapat ditempat itu.

b. Segala sesuatu yang diperoleh debitur dari pekerjaannya sendiri sebagai penggajian dari suatu jabatan atau jasa, sebagai upah, pensiun, uang tunggu atau tunjangan, sejauh yang ditentukan oleh hakim pengawas.

c. Uang yang diberikan kepada debitur untuk memenuhi suatu kewajiban memberi nafkah menurut undang-undang.

\section{Akibat Kepailitan terhadap Pasangan (Suami/Istri) Debitur Pailit}

Debitur pailit yang pada saat dinyatakan pailit sudah terkait dalam suatu perkawinan yang sah dan adanya persatuan harta, kepailitannya juga dapat memberikan akibat hukum terhadap pasangannya. Dalam hal suami atau istri yang dinyatakan pailit, istri atau suaminya berhak mengambil semua benda bergerak dan tidak bergerak yang merupakan harta bawaan dari istri atau suami dan harta yang diperoleh masingmasing sebagai hadiah atau warisan. Jika benda milik istri atau suami telah dijual oleh suami atau istri dan harganya belum dibayar dan hasil penjualan tersebut belum tercampur dalam harta pailit maka istri atau suami berhak mengambil kembali uang hasil penjualan tersebut.

\section{Akibat Kepailitan terhadap Seluruh Perikatan yang Dibuat Debitur Pailit \\ Semua perikatan debitur yang} terbit sesudah putusan pernyataan pailit, tidak lagi dapat dibayar dari harta pailit, kecuali perikatan tersebut menguntungkan harta pailit. Tuntutan mengenai hak atau kewajiban yang menyangkut harta pailit harus diajukan oleh atau terhadap kurator. Dalam hal tuntutan tersebut diajukan atau diteruskan oleh atau terhadap debitur pailit, maka apabila tuntutan tersebut mengakibatkan suatu penghukuman terhadap debitur pailit, penghukuman tersebut tidak mempunyai akibat hukum terhadap harta pailit. (Pasal 26 UU Kepailitan).

Selama berlangsungnya kepailitan, tuntutan untuk memperoleh pemenuhan perikatan dari harta pailit yang ditujukan terhadap debitur pailit, hanya dapat diajukan dengan mendaftarkan dan di cocokkan. (Pasal 27 UU Kepailitan).

4. Akibat Kepailitan terhadap Seluruh Perbuatan Hukum Debitur yang Dilakukan Sebelum Putusan Pernyataan Pailit Diucapkan.

Dalam pasal 41 ayat $1 \mathrm{UU}$ Kepailitan dinyatakan secara tegas bahwa untuk kepentingan harta pailit, segala perbuatan hukum debitur yang telah dinyatakan pailit 
yang merugikan kepentingan kreditor, yang dilakukan sebelum putusan pernyataan pailit diucapkan, dapat dimintai pembatalan kepada pengadilan.

\section{KESIMPULAN}

1. Tanggungjawab perseroan terbatas dalam hal terjadinya kepailitan dipertanggungjawabkan oleh perseroan terbatas serta Kurator untuk melakukan pemberesan harta kekayaan guna pembayaran bagi pihak ketiga atau debitur, agar debitur tidak mengalami kerugian. Jika hal itu terjadi karena kesalahan dan kelalaian direksi dan komisaris maka kerugian dalam hal ini akan dipikulkan kepadanya.

2. Akibat hukum dari kepailitan perseroan terbatas adalah pengubahan status hukum perseroan menjadi tidak cakap melakukan perbuatan hukum dan tidak bisa melakukan pengurusan harta kekayaan, yang kemudian hanya bisa dilakukan oleh kurator. Bagi debitur akan kehilangan kecakapannya untuk melakukan perbuatan hukum dan wewenang dalam mengurus dan mengalihkan harta kekayaannya.

\section{DAFTAR PUSTAKA}

\section{A. Buku-Buku}

Adi, Susanti. 2018. Hukum Kepailitan di Indonesia dalam Teori dan Praktek serta Penerapannya Hukumnya. Jakarta: Divisi Kencana

Ali, Zainuddin. 2011. Metode Penelitian Hukum. Jakarta: Sinar Grafika

Fuady, Mudir. 1998. Hukum Pailit dalam Teori dan Praktek. Bandung: Citra Aditya Bakti

Jono. 2007. Hukum Kepailitan. Tangerang: Sinar Grafika

Muhammad, Abdulkadir.2014. Hukum Perdata Indonesia. Bandung:Citra Aditya Bakti Nadapdap, Binoto. 2017. Hukum Perseroan Terbatas. Jakarta: Aksara
Patrik, Purwahid.1994. Dasar-dasar Hukum Kepailitan. Bandung: Mandar Maju

Prasetya, Rudhi. 2003. Firma dan Persekutuan Komanditer. Bandung: Citra Aditya Bakti

Regar, Moenaf. 2005.Dewan Komisaris Peranannya sebagai Organ Perseroan. Jakarta:Budi Aksara

Shubhan, Hadi. 2008. Hukum Kepailitan Prinsip Norma dan Praktik di Peradilan. Jakarta: Kencana

Soekanto, Soerjono. 1982. Sosiologi Hukum dalam Masyarakat. Jakarta: Rajawali Press

Subekti, R. 2005. Hukum Perjanjian. Bali: Internasa

Subekti. 2006. Pokok-pokok Hukum Perdata. Jakarta: Internasa

\section{B. Perundang-Undangan}

Undang-Undang Dasar 1945

Perdata Kitab Undang-undang Hukum Undang-undang Nomor 37 tahun 2004 tentang Kepailitan Undang-undang Nomor 40 tahun 2007 tentang Perseroan Terbatas

\section{Internet}

Hukumperseroanterbatas.com. Semua tentang Perseroan Terbatas (diakses $30 \mathrm{Juli} \quad 2020,10.32 \mathrm{WIB}$ )

Hukumonline.com. Peranan Kurator (diakses 24 Juli 2020, 10.35 WIB)

plawyer.co.id. Tugas Kurator dalam Kepailitan Perseroan Terbatas (diakses $24 \mathrm{Juli} \quad 2020, \quad 11.30$ WIB)

Journal.udin-alauddin.ac.id. Akibat Kepailitan Perseroan Terbatas (diakses 27 Juli 2020, 21.23 WIB)

http://sinta.unud.ac.id. Tujuan Lembaga Kepailitan (diakses 29 Juli 2020, 21.44 WIB) 